\title{
Efektivitas Model STAD terhadap Hasil Belajar Matematika Ditinjau dari Self Efficacy Peserta Didik Kelas 5 SDN 1 Sidorahayu
}

\author{
Jaelani $^{1}$, Meriyati ${ }^{2}$, Mukti Amini ${ }^{3}$, Komarudin $^{4}$ \\ ${ }^{1}$ Post Graduate Program Indonesia Open University, ${ }^{2}$ UIN Raden Intan Lampung \\ ${ }^{3}$ Post Graduate Program Indonesia Open University, ${ }^{4}$ UIN Raden Intan Lampung \\ 1jaelani.ut1@gmail.com, ${ }^{2}$ meriyati@radenintan.ac.id, \\ ${ }^{3}$ muktiamini.ut1@gmail.com, ${ }^{4}$ komarudin@ radenintan.ac.id
}

\begin{tabular}{l}
\hline \hline Article Info \\
\hline Article history: \\
Received Mar $20^{\text {th }}, 2019$ \\
Revised April $28^{\text {th }}, 2019$ \\
Accepted April $29^{\text {th }}, 2019$ \\
\hline
\end{tabular}

Keywords:

Mathematics;

Self Efficacy;

STAD

\begin{abstract}
This study aims to determine the effectiveness of cooperative learning model on the STAD (Student Team Achievement Division) type reviewed from students' self efficacy toward mathematics learning outcomes. In this study, the hypothesis test uses two way anava analysis with a significance level of $\alpha=0.05$. The population of this study was the fifth grade students of SDN 1 Sidorahayu which are divided into two study groups. Meanwhile, the sample of this study is students in the fifth grade who also divided into two study groups. Test results show that the test instruments are valid with a reliability index of $r_{11}>0.70$ and a difficulty index of $p>$ 0.70 for easy criteria, and $p<0.30$ for difficult criteria. The outcomes of this study indicate that there are no significant results from the cooperative learning model on the STAD type toward the mathematics learning outcomes in terms of self efficacy of the 5th grade students in SDN 1 Sidorahayu. Whereas, there is a positive interaction between the STAD learning model and self efficacy on students' mathematics learning outcomes, in which students with high self efficacy have better mathematics learning outcomes than students with low self efficacy.
\end{abstract}

Kata Kunci:

Matematika;

Self Efficacy; STAD

\section{Abstrak}

Penelitian ini bertujuan untuk mengetahui efektivitas model pembelajaran kooperatif tipe STAD ditinjau dari self efficacy peserta terhadap hasil belajar matematika. 
40 | Jaelani, Meriyati, Amini, Komarudin: Efektifitas Model STAD Terhadap Hasil Belajar...

Uji hipotesis dalam penelitian ini menggunakan analisis two way anava dengan tingkat signifikansi $\alpha=0,05$. Populasi penelitian ini adalah peserta didik kelas 5 SDN 1 Sidorahayu yang terbagi menjadi dua rombongan belajar (rombel). Sedangkan sampel penelitian ini adalah peserta didik kelas 5 yang juga terbagi menjadi dua rombel. Hasil uji instrumen tes menunjukan bahwa instrumen tes valid dengan indeks reliabilitas $r_{11}>0,70$ dan indeks kesukaran sebesar $p>0,70$ untuk kriteria mudah, $p<0,30$ untuk kreteria sukar. Hasil penelitian ini menunjukkan bahwa tidak terdapat hasil yang signifikan dari model pembelajaran kooperatif tipe STAD terhadap hasil belajar matematika ditinjau dari self efficacy peserta didik kelas 5 SDN 1 Sidorahayu. Kemudian, terdapat interaksi positif antara model pembelajaran STAD dengan self efficacy terhadap hasil belajar matematika peserta didik, dimana hasil belajar matematika peserta didik yang memiliki self efficacy tinggi lebih baik dibandingkan hasil belajar matematika peserta didik yang memiliki self efficacy rendah.

\section{PENDAHULUAN}

Isu peningkatan mutu pembelajaran dan efektivitas pembelajaran memang perlu ditindaklanjuti di antaranya dengan menyelenggarakan pembelajaran yang efektif. Guru Sekolah Dasar (SD) harus yakin bahwa ketika pembelajaran selesai semua peserta didik telah menguasai indikator kompetensi dasar yang diharapkan. Melalui evaluasi berbasis kelas, informasi tentang penguasaan materi pembelajaran akan segera diketahui oleh guru dan informasi ini menjadi bekal refleksi pembelajaran yang lebih efektif pada masa berikutnya.

Von Glaserfeld menyatakan bahwa constructivision is a theory of knowledge with roots in philosophy, psycology, and cybernetics (Murphy 1997; Simbolon 2013). Konstruktivisme bertitik tolak dari pembentukan pengetahuan, dan rekonstruksi pengetahuan adalah mengubah pengetahuan yang dimiliki seseorang yang telah dibangun atau dikonstruk sebelumnya dan perubahan itu sebagai akibat dari interaksi dengan lingkungannya (Effendi dan Aini 2018; Subakti 2017; Dodi 2016; 
Paradesa 2015; Manalu 2014; Susila, Corebima, dan Handayani 2013). Menurut Sumantri (2015:59) mengatakan model pembelajaran kooperatif dinyatakan sebagai rangkaian kegiatan pembelajaran yang dilakukan oleh peserta didik dalam kelompok-kelompok tertentu untuk mencapai tujuan pembelajaran yang telah dirumuskan (Lamba 2016; Fathurrohman 2015; Yensy 2012; Ismawati dan Hindarto 2011). Salah satu model pembelajaran kooperatif tersebut adalah model pembelajaran STAD (Student Team Achievement Division). Model pembelajaran kooperatif tipe STAD merupakan pembelajaran yang terdiri empat sampai lima peserta didik yang akan ditugaskan ke berbagai kelompok yang terdiri dari tingkat diferensiasi tertentu: kompetensi, jenis kelamin, ras, dan sebagainya (heterogen) (Agustina 2015; Rahayu 2014; Marheni, Sujana, dan Putra 2013; Jarmita 2012; Widowati 2011). Bandura (1997) self efficacy merupakan bentuk kepercayaan diri peserta didik bahwa dirinya memiliki kemampuan dalam menjalankan tugas dan mampu mencapai tujuan (Sariningsih dan Purwasih 2017; Subaidi 2016; Utami 2013; Widyastuti 2013; Pudjiastuti 2012).

Berdasarkan latar belakang di atas, penelitian ini bertujuan untuk mengetahui: (1) efektivitas model pembelajaran kooperatif tipe STAD terhadap hasil belajar matematika peserta didik kelas 5 SDN 1 Sidorahayu tahun ajaran 2018/2019; (2) efektifitas self efficacy terhadap hasil belajar matematika peserta didik kelas 5 SDN 1 Sidorahayu tahun ajaran 2018/2019; dan (3) interaksi antara model pembelajaran dan self efficacy terhadap hasil belajar matematika peserta didik kelas 5 SDN 1 Sidorahayu tahun ajaran 2018/2019.

\section{METODE PENELITIAN}

Penelitian ini dilaksanakan di SDN 1 Sidorahayu Kecamatan Waway Karya Kabupaten Lampung Timur pada semester Ganjil Tahun 2018/2019. Populasi penelitian ini adalah seluruh peserta didik kelas 5 SDN 1 Sidorahayu, selanjutnya pengambilan sampel dilakukan dengan teknik Cluster Random Sampling dan diperoleh kelas 5.A dan 5.B sebagai kelas eksperimen dan kelas kontrol. Teknik pengumpulan data dilakukan 
42 | Jaelani, Meriyati, Amini, Komarudin: Efektifitas Model STAD Terhadap Hasil Belajar...

dengan teknik tes dan angket (quetioner). Instrumen yang digunakan adalah tes hasil belajar matematika dan angket self efficacy. Analisis data dilakukan dengan menggunakan anava dua jalan (two way anova) dan dilanjutkan dengan dengan uji Scheffe.

\section{HASIL PENELITIAN DAN PEMBAHASAN}

Sebelum dilakukan uji hipotesis, terlebih dilakukan uji prasyarat, yaitu meliputi uji normalitas dan uji homogenitas.

\section{Uji Normalitas}

Untuk mengetahui apakah sampel berasal dari populasi yang berdistribusi normal atau tidak dengan uji normalitas. Dengan taraf signifikansi 0,05, rangkuman hasil uji normalitas menggunakan model Lilliefors dengan SPSS terhadap data hasil belajar matematika peserta didik disajikan dalam tabel berikut.

Tabel 1. Hasil Uji Normalitas Hasil Belajar Peserta didik

Tests of Normality

\begin{tabular}{|c|c|c|c|c|c|c|c|}
\hline & \multicolumn{4}{|c|}{ Kolmogorov-Smirnov $^{\mathrm{a}}$} & \multicolumn{2}{|c|}{ Shapiro-Wilk } \\
\hline & & Statistic & $\mathrm{df}$ & Sig. & Statistic & $\mathrm{df}$ & Sig. \\
\hline $\begin{array}{l}\text { Standardized } \\
\text { for HASIL }\end{array}$ & Residual & 127 & 44 & .073 & .953 & 44 & .073 \\
\hline
\end{tabular}

a. Lilliefors Significance Correction

Berdasarkan hasil uji normalitas dengan SPSS 22 diperoleh nilai signifikan sebesar $0,073>0,05$ ini berarti setiap sampel adalah berdistribusi normal.

\section{Uji Homogenitas}

Uji homogenitas dilakukan untuk melihat apakah populasi-populasi yang dibandingkan mempunyai variansi yang sama (homogen) atau tidak. Uji homogenitas variansi ini dilakukan terhadap 2 kelompok sampel. Dengan taraf signifikansi sebesar 0,05 , rangkuman hasil uji homogenitas variansi menggunakan uji Bartlett pada data hasil belajar matematika peserta didik. 
Tabel 2. Uji Homogenitas Hasil Belajar Peserta didik Levene's Test of Equality of Error Variances ${ }^{\text {a }}$

\begin{tabular}{llcc}
\hline \multicolumn{4}{c}{ Dependent Variable: Hasil Belajar Matematika } \\
\hline $\mathrm{F}$ & $\mathrm{df1}$ & $\mathrm{df} 2$ & Sig. \\
\hline .653 & 3 & 40 & .586 \\
\hline
\end{tabular}

Tests the null hypothesis that the error variance of the dependent variable is equal across groups.

Berdasarkan hasil uji homogenitas variansi dengan SPSS 22, diperoleh nilai sig. sebesar $0,586>0,05$. Dengan demikian, dapat disimpulkan bahwa varian variabel hasil belajar matematika adalah homogen. Sehingga asumsi homogenitas dalam uji two way anova terpenuhi.

\section{Pengujian Hipotesis}

Pengujian hipotesis dilakukan untuk mengetahui apakah terdapat pengaruh model pembelajaran dan self efficacy terhadap hasil belajar matematika. Oleh karena kesimpulan hasil uji prasyarat bahwa semua sampel berasal dari populasi yang berdistribusi normal dan populasipopulasi yang dibandingkan mempunyai variansi yang sama (homogen), maka pengujian hipotesis ini dapat dilakukan dengan anava dua jalur .

Hasil perhitungan anava dua jalur dengan taraf signifikansi sebesar 0,05 , disajikan dalam tabel berikut.

Tabel 3. Analisis Variansi dua Jalur

\begin{tabular}{lcccccc}
\hline \multicolumn{1}{c}{ Source } & $\begin{array}{c}\text { Type III Sum } \\
\text { of Squares }\end{array}$ & df & Square & F & Sig. & Squared \\
\hline Corrected Model & $1134.845 \mathrm{a}$ & 3 & 378.282 & 9.711 & .000 & .421 \\
Intercept & 228127.257 & 1 & 228127.257 & 5856.428 & .000 & .993 \\
Kelas & 354.563 & 1 & 354.563 & 9.102 & .004 & .185 \\
Self_Efficacy & 322.911 & 1 & 322.911 & 8.290 & .006 & .172 \\
Kelas * & 78.602 & 1 & 78.602 & 2.018 & .163 & .048 \\
Self_Efficacy & 1558.132 & 40 & 38.953 & & & \\
Error & 270233.000 & 44 & & & & \\
Total & 2692.977 & 43 & & & & \\
Corrected Total & R Squared =.421 (Adjusted R Squared = .378) & & & \\
R Squal &
\end{tabular}


44 | Jaelani, Meriyati, Amini, Komarudin: Efektifitas Model STAD Terhadap Hasil Belajar...

Berdasarkan hasil analisis variansi dua jalur menggunakan SPSS, dengan taraf signifikansi 0,05 diperoleh kesimpulan sebagai berikut:

Kesatu, diperoleh nilai signifikansi sebesar 0,004 $<0,05$, hipotesis pertama ditolak, sehingga dapat disimpulkan bahwa ada perbedaan hasil belajar peserta didik antara model pembelajaran pembelajaran tipe STAD dan model pembelajaran konvensional terhadap hasil belajar matematika ditinjau dari self efficacy .

Kedua, diperoleh nilai signifikansi sebesar 0,006 $<0,05$, hipotesis pertama ditolak, artinya ada perbedaan hasil belajar matematika antara peserta didik yang mempunyai self efficacy tinggi dengan peserta didik yang mempunyai self efficacy rendah. Baik untuk kelas yang dikenai model pembelajaran tipe STAD maupun kelas dengan model pembelajaran konvensional.

Ketiga, diperoleh nilai signifikansi sebesar 0,163>0,05, hipotesis pertama diterima, artinya tidak ada interaksi antara model pembelajaran dan self efficacy terhadap hasil belajar matematika peserta didik. Dengan kata lain, tidak ada perbedaan hasil belajar matematika peserta didik pada masing-masing kategori model pembelajaran tidak konsisten terhadap masing-masing kategori self efficacy atau tidak ada perbedaan hasil belajar matematika peserta didik pada masing-masing kategori self efficacy yang tidak konsisten terhadap masing-masing kategori model pembelajaran.

Berdasarkan hasil penelitian dan pengujian hipotesis, berikut adalah penjelasan dari ketujuh hipotesis penelitian.

\section{Hipotesis Pertama}

Dari hasil perhitungan analisis variansi dua jalur diperoleh nilai signifikan sebesar 0,004 > 0,05. Oleh karena itu, $\mathrm{H}_{0}$ ditolak. Hal ini berarti penerapan model pembelajaran kooperatif tipe STAD lebih efektif daripada model pembelajaran konvensional terhadap hasil belajar matematika peserta didik. Dengan kata lain, terdapat perbedaan hasil belajar matematika yang signifikan antara peserta didik yang dikenai model pembelajaran kooperatif tipe STAD dengan model pembelajaran konvensional. Hal ini ada kesamaan dengan penelitian yang dilakukan 
K.V. Zaki, S. Dkk., (2013) yang dalam hasil penelitiannya menunjukkan bahwa model pembelajaran STAD dapat digunakan untuk meningkatkan pemahaman dan hasil belajar peserta didik.

\section{Hipotesis Kedua}

Berdasarkan hasil perhitungan anava dua jalur diperoleh nilai signifikan sebesar $0,006>0,05$. Oleh karena itu, $\mathrm{H}_{0}$ ditolak. Hal ini menunjukkan bahwa terdapat perbedaan pengaruh antar masing-masing kategori self efficacy peserta didik terhadap hasil belajar matematika peserta didik. Berdasarkan hasil uji rerata antar kolom pada masingmasing klasifikasi self efficacy, dapat disimpulkan bahwa hasil belajar matematika peserta didik yang memiliki self efficacy tinggi lebih baik dibandingkan hasil belajar matematika peserta didik yang memiliki self efficacy rendah. Hasil penelitian ini sesuai dengan hipotesis penelitian. Hal ini sesuai dengan pendapat Monika A. dkk., (2017) hasil penelitiannya menunjukan bahwa ada hubungan antara variabel berjalur satu arah dimana semakin tinggi self efficacy peserta didik, maka semakin tinggi hasil belajarnya.

\section{Hipotesis Ketiga}

Hasil perhitungan anava dua jalur diperoleh nilai signifikan sebesar $0,163>0,05$. Oleh karena itu, $\mathrm{H}_{0}$ diterima. Hal ini menunjukkan bahwa tidak terdapat interaksi antara model pembelajaran dan self efficacy terhadap hasil belajar matematika. Dengan kata lain, perbedaan hasil belajar matematika peserta didik pada masing-masing kategori model pembelajaran konsisten terhadap masing-masing kategori self efficacy . Hal ini selaras dengan hasil penelitian yang dilakukan oleh Maratu Shalikhah, Budi Usodo, Sri Subanti, (2016:54) yang menunjukan bahwa prestasi belajar matematika self efficacy sedang sama dengan peserta didik self efficacy rendah.

Hasil penelitian ini tidak sesuai dengan hipotesis penelitian. Hal ini juga tidak sesuai dengan kajian teori yang menyatakan bahwa dengan menerapkan model pembelajaran kooperatif tipe STAD diharapkan akan 
46 | Jaelani, Meriyati, Amini, Komarudin: Efektifitas Model STAD Terhadap Hasil Belajar...

bisa membuat pembelajaran menjadi lebih efektif. Saling bekerja sama antar anggota kelompok dalam pembelajaran membuat peserta didik lebih aktif sehingga model pembelajaran kooperatif tipe STAD lebih efektif.

Tidak terpenuhinya hipotesis pertama ini mungkin dipengaruhi oleh beberapa faktor, antara lain: pertama, kegiatan yang dilakukan pada kedua model yang diberikan secara umum peserta didik dari kedua kelompok eksperimen tersebut sama-sama menunjukkan antusias yang tinggi karena mendapatkan model pembelajaran yang berbeda dari yang pernah mereka dapat sebelumnya, sehingga hasil belajar matematika dari peserta didik pada kedua kelompok tersebut cenderung sama atau tidak terdapat perbedaan yang signifikan; kedua, kurang optimalnya kemampuan guru dalam menggunakan model pembelajaran kooperatif tipe STAD, sehingga dalam pelaksanaannya tidak memberikan perbedaan yang signifikan antara model pembelajaran kooperatif tipe STAD dengan model pembelajaran konvensional.

Kondisi penelitian juga tidak bisa berjalur efektif, hal ini disebabkan oleh faktor lingkungan yaitu kondisi kelas yang masih ada kursi dan bangku yang tidak tersusun dengan rapi. Kondisi tersebut hanya sedikit mempengaruhi suasana belajar. Untuk itu, bagi peneliti lain yang ingin melakukan penelitian, sebaiknya mempersiapkan dengan melakukan observasi terlebih dahulu, sehingga proses pembelajaran dapat berjalur dengan efektif.

\section{SIMPULAN}

Berdasarkan hasil penelitian dan pembahasan dapat disimpulkan bahwa terdapat perbedaan hasil belajar matematika yang signifikan antara peserta didik yang dikenai model pembelajaran kooperatif tipe STAD dan peserta didik yang dikenai model pembelajaran kovensional terhadap hasil belajar matematika pada pokok bahasan bilangan berpangkat dua dan akar pangkat dua, dan hasil belajar matematika peserta didik yang memiliki self efficacy tinggi lebih baik dibandingkan hasil belajar matematika peserta didik yang memiliki self efficacy rendah terhadap hasil belajar matematika pada pokok bahasan bilangan berpangkat dua 
dan akar pangkat dua, serta tidak terdapat interaksi antara model pembelajaran dan self efficacy terhadap hasil belajar matematika pada pokok bahasan bilangan berpangkat dua dan akar pangkat dua.

\section{DAFTAR PUSTAKA}

Agustina, Radiatul Laila. (2015). Upaya Meningkatkan Hasil Belajar IPA Siswa Kelas IV Menggunakan Model STAD dan NHT. Journal of Educational Science and Technology (EST), 1(3), 31-38. Retrieved from http://ojs.unm.ac.id/index.php/JEST/article/view/1801

Dodi, Nofri. (2016). Penerapan Pendekatan Konstruktivistik Dalam Pendidikan Bagi Anak Usia Dini dalam Rangka Peningkatan Kualitas Pembelajaran. Journal Educative: Journal of Educational Studies, 1(2), 154-67. Retrieved from http://ejournal.iainbukittinggi.ac.id/index.php/educative/article/view $/ 161 / 0$

Effendi, Kiki Nia Sania, dan Indrie Noor Aini. (2018). Pelatihan Penyusunan Lembar Kerja Siswa (LKS) Bagi Guru Matematika SMP di Telukjambe, Karawang. Jurnal Pengabdian Pada Masyarakat 3 (1), 45-52. Retrieved from http://ppm.ejournal.id/index.php/pengabdian/article/view/38

Fathurrohman, Muhammad. (2015). Model-Model Pembelajaran. Jogjakarta: Ar-Ruzz Media.

Ismawati, Nurul, dan N. Hindarto. (2011). Penerapan Model Pembelajaran Kooperatif dengan Pendekatan Struktural Two Stay Two Stray untuk Meningkatkan Hasil Belajar Siswa Kelas X SMA. Jurnal Pendidikan Fisika Indonesia, 7 (1), 38-41. Retrieved from http://journal.unnes.ac.id/nju/index.php/JPFI/article/view/1067

Jarmita, Nida. (2012). Penerapan Pembelajaran Kooperatif Tipe STAD dalam Meningkatkan Pemahaman Matematis Siswa pada Pokok Bahasan Bangun Ruang. JURNAL ILMIAH DIDAKTIKA: Media Ilmiah Pendidikan dan Pengajaran, 13 (1), 150-172. Retrieved from http://jurnal.ar-raniry.ac.id/index.php/didaktika/article/view/ 470 
48 | Jaelani, Meriyati, Amini, Komarudin: Efektifitas Model STAD Terhadap Hasil Belajar...

Juli Widyastuti, Retno. (2013). Pengaruh Self Efficacy dan Dukungan Sosial Keluarga Terhadap Kemantapan Pengambilan Keputusan Karir Siswa. Jurnal BK UNESA, 3 (1), 231-238. Retrieved from https://jurnalmahasiswa.unesa.ac.id/index.php/jurnal-bk-unesa/ article/view/3369

Lamba, Hendrik Arung. (2016). Pengaruh Pembelajaran Kooperatif Model STAD dan Gaya Kognitif Terhadap Hasil Belajar Fisika Siswa SMA. Jurnal Ilmu Pendidikan, 13 (2), 122-128. Retrieved from http://journal.um.ac.id/index.php/jip/article/view/55

Manalu, effendi. (2014). Penerapan Pendekatan Konstruktivis Sosial dalam." Jurnal Handayani PGSD FIP Unimed, 2 (1), 13-23, Retrieved from http://jurnal.unimed.ac.id/2012/index.php/handayani/article/view/ 1733

Marheni, Ni L. Gd, I. Wyn Sujana, dan DB Kt Ngr Semara Putra. (2013). Penerapan Model Pembelajaran Kooperatif Tipe STAD untuk Meningkatkan Keaktifan dan Hasil Belajar IPS Kelas V SD No. 8 Padangsambian Denpasar. MIMBAR PGSD Undiksha, 1 (1), Retrieved from

https://ejournal.undiksha.ac.id.index.php/JJPGSD/article/view/1438 Murphy, Elizabeth. (1997). Constructivism: From Philosophy to Practice. Retrieved from https://eric.ed.gov/?id=ED444966

Paradesa, Retni. (2015). Kemampuan Berpikir Kritis Matematis Mahasiswa Melalui Pendekatan Konstruktivisme pada Mata Kuliah Matematika Keuangan. Jurnal Pendidikan Matematika RAFA, 1 (2), 306-25. Retrieved from

http://jurnal.radenfatah.ac.id.index.php/jpmrafa/article/view/1236

Pudjiastuti, Endang. (2012). Hubungan 'Self Efficacy' dengan Perilaku Mencontek Mahasiswa Psikologi. MIMBAR, Jurnal Sosial dan Pembangunan, 28 (1), 103-11. Retrieved from https://ejournal.unisba.ac.id/index.php/mimbar/article/view/344

Rahayu, Riska. (2014). Peningkatan Kemampuan Komunikasi dan Pemecahan Masalah Matematis Siswa SMP Ar-Rahman Percut 
melalui Pembelajaran Kooperatif Tipe Student Teams Achievement Division (STAD). Paradikma Jurnal Pendidikan Matematika, 7(1), Retrieved from http://id.portalgaruda.org/?ref=browse \& mod=viewarticle \&article=2 81872

Sariningsih, Ratna, dan Ratni Purwasih. (2017). Pembelajaran Problem Based Learning untuk Meningkatkan Kemampuan Pemecahan Masalah Matematis dan Self Efficacy Mahasiswa Calon Guru. JNPM (Jurnal Nasional Pendidikan Matematika), 1 (1), 163-77. Retrieved from http://jurnal.unswagati.ac.id/index.php/JNPM/article/view/275

Simbolon, Pommer. (2013). Upaya Meningkatkan Kemampuan Pemecahan Masalah Matematis Siswa Melalui Penerapan Model Pembelajaran Matematika Berdasarkan Masalah Berbasis Budaya Batak (PBM-B3) pada Kelas XII IPS SMA Negeri 1 Galang. UNIMED. Retrieved from http://digilib.unimed.ac.id/3942

Subaidi, Agus. (2016). Self-Efficacy Siswa dalam Pemecahan Masalah Matematika. Jurnal Sigma, 1 (2), 64-68. Retrieved from http://ejournal.unira.ac.id/index.php/jurnal_sigma/article/view/68

Subakti, Subakti. (2017). Pengaruh Model Pembelajaran Konstruktivisme Terhadap Ketepatan Servis Bawah dalam Permainan Bola Voli Siswa. Gelora: Jurnal Pendidikan Olahraga dan Kesehatan, 4 (1), 54-61. Retrieved from http://ojs.ikipmataram.ac.id/index.php/ gelora/article/view/565/0

Susila, Rudy Indranatan, Aloysius Duran Corebima, dan Nursasi Handayani. (2013). Pengaruh Waktu Pemberian Lembar Kerja Siswa PBL Melalui Strategi Problem Based Learning Terhadap Peningkatan Hasil Belajar Kognitif Biologi dan Retensi Siswa Kelas XI MAN Kota Malang. Jurnal Online UM, 2(1), Retrieved from http://jurnal-online.um.ac.id/article/do/detail/article/1/33/1102 Utami, Yudi Ganing Dwi. (2013). Self Efficacy dengan Kesiapan Kerja Siswa Sekolah Menengah Kejuruan. Jurnal Ilmiah Psikologi 
50 | Jaelani, Meriyati, Amini, Komarudin: Efektifitas Model STAD Terhadap Hasil Belajar...

Terapan, 1 (1), 40-52. Retrieved from http://ejournal.umm.ac.id.index.php/jipt/article/view/1356

Widowati, Hening. (2011). Penerapan Pembelajaran Kooperatif Model Examples Non Examples dan STAD Pada Mata Kuliah Struktur Hewan Program Studi Pendidikan Biologi. BIOEDUKASI (Jurnal Pendidikan Biologi), 2 (1), 1-10. Retrieved from http://ojs.fkip/ummetro.ac.id/index.php/biologi/article/view/202/167 Yensy, Nurul Astuty. (2012). Penerapan Model Pembelajaran Kooperatif Tipe Examples Non Examples dengan Menggunakan Alat Peraga untuk Meningkatkan Hasil Belajar Siswa di Kelas VIII SMP N 1 Argamakmur. Exacta, 10 (1), 24-35. Retrieved from http://repository.unib.ac.id/940 